\title{
Article \\ Microbiological Safety and Organoleptic Quality of Homogenized Sausages Manufactured with Commercial Functional Additives
}

\author{
Anna Fudali ${ }^{1}$, Iwona Chełmecka ${ }^{2}$, Anna Marietta Salejda ${ }^{1, *}$ ib and Grażyna Krasnowska ${ }^{1}$ \\ 1 Faculty of Biotechnology and Food Science, Wroclaw University of Environmental and Life Sciences, \\ 51-603 Wrocław, Poland; annaszady@wp.pl (A.F.); grazyna.krasnowska@upwr.edu.pl (G.K.) \\ 2 Jerzy Gawrycki Meat Processing Plant, 58-260 Bielawa, Poland; iwona.chelmecka222@gmail.com \\ * Correspondence: anna.salejda@upwr.edu.pl
}

\section{check for} updates

Citation: Fudali, A.; Chełmecka, I. Salejda, A.M.; Krasnowska, G. Microbiological Safety and Organoleptic Quality of Homogenized Sausages Manufactured with Commercial Functional Additives. Appl. Sci. 2021, 11, 11662. https://doi.org/10.3390/ app112411662

Academic Editor: Małgorzata Karwowska

Received: 15 November 2021 Accepted: 2 December 2021 Published: 8 December 2021

Publisher's Note: MDPI stays neutral with regard to jurisdictional claims in published maps and institutional affiliations.

Copyright: (c) 2021 by the authors. Licensee MDPI, Basel, Switzerland. This article is an open access article distributed under the terms and conditions of the Creative Commons Attribution (CC BY) license (https:// creativecommons.org/licenses/by/ $4.0 /)$.

\begin{abstract}
The aim of the study was to compare the microbiological safety and sensory quality of meat products manufactured with commercial functional additives. Four functional additives (AFX, AE100, PANA4, FPRX) were used in industrial conditions in the production of homogenized meat products (thick wiener). In order to determine the microbiological safety of final products, the total number of aerobic mesophilic bacteria and the number of Listeria monocytogenes were measured. Consumer assessment and quantitative flavor profiling (QFP) were used for analysis of organoleptic quality. After 7 days of storage, it was found that the effectiveness of the selected additives against the growth of aerobic mesophilic bacteria was unsatisfactory. Only after application of PANA4 did the product not show undesirable changes that would disqualify it from consumption. Each of the functional additives used had a high level of efficacy in inhibiting the growth of Listeria monocytogenes. Meat products with PANA4 addition had the highest consumer acceptance of the overall appearance. The best intensity of flavor bouquet, meat aroma and color, assessed by QFP method, was characterized by the samples with AFX and PANA4 in their recipe.
\end{abstract}

Keywords: additives; sausages; microbial growth; QFP; quality

\section{Introduction}

Meat and meat products are perishable due to their chemical composition. Their shelf life is limited by the development of undesirable microflora, enzyme activity or oxidation processes [1]. The growth of undesirable microflora leads to a decrease in sensory quality of food and, particularly, its safety. Proliferating bacteria can cause foodborne infection and intoxication. Therefore, it is crucial to reduce the possibility of the above-mentioned health hazard occurrence in food [2]. The health safety of food, including meat products, can be ensured by the use of functional additives, proper processing and packaging, and maintaining refrigerated storage conditions [1]. In the meat industry, chemical food additives are used to control specific microorganisms. Many chemicals show potential as food preservatives, but only a few are approved for use in food production. According to Regulation (EC) No 1333/2008, food "preservatives are substances which prolong the shelflife of foods by protecting them against deterioration caused by micro-organisms and/or which protect against growth of pathogenic micro-organisms" [3]. They should be used at the lowest possible dose (less than $0.2 \%$ ) to achieve the intended effect [4]. The amount that may be used and the residue that may be left in food products are strictly defined by food law, e.g., Commission Regulation (EU) No 1129/2011 [5]. Commission Regulation (EU) No 1129/2011 permits the use of only a few chemical additives to meat preservation, e.g., nitrites (potassium and sodium nitrite), nitrates (potassium and sodium nitrates), sodium ascorbate, and sorbic acid. These substances may only be added to a specific category of meat products; thus, it is important to define it correctly. For instance, sorbic 
acid can be added at quantum satis to surface treatment of dried meat product (category: non-heat-treated processed meats), but only in strictly defined quantities $(1000 \mathrm{mg} / \mathrm{kg})$ to pâté (category: heat-treated processed meats). Despite legal restrictions, some consumers are wary of chemical food additives and are more interested in using natural substances derived from plants and plant materials to preserve and improve meat quality [6]. Food producers and technologists are trying to meet those expectations by creating new recipes of meat products based on natural ingredients [4]. Essential oils or extracts derived from plants, such as oregano [7], clove [8], sage [9], marjoram [10], garlic [11] are used in meat systems as natural preservatives. Therefore, this study provides the information on the effect of commercial functional additives containing spice extracts on microbiological safety and sensory quality of homogenized meat products.

\section{Materials and Methods}

\subsection{Preparation of Experimental Material}

The experimental material consisted of homogenized meat products (sausages, thick wiener-type) produced in industrial conditions (Jerzy Gawrycki Meat Processing Plant, Bielawa, Poland). Two production batches of sausages were carried out. The recipe of sausages is shown in Table 1. Raw materials, i.e., pork class II (without bones, medium fat, with some tendons, up to $10 \mathrm{~mm}$ of intermuscular fat, total fat up to $30 \%$ ) and beef class II (without bones, lean, with some tendons, intermuscular fat up to $2 \mathrm{~mm}$, total fat up to $16 \%$ ) were dry cured with curing salt and kept refrigerated until use. On the day of production, pork, beef and skinless pork jowl were ground (WW 130, K + W Wetter, Germany) through a $0.3 \mathrm{~cm}$ plate, and then beef and pork with all the additives were minced with ice water. Then the jowl was added and further minced (KN-1-60, Metalbud, Poland) until the ingredients were completely emulsified and the water was absorbed. Stuffings were placed in natural sausage casings, forming $6 \mathrm{~cm}$ long bars that were left in coils. The bars were then set for $20 \mathrm{~min}$ at $20-30{ }^{\circ} \mathrm{C}$ and hot smoked $\left(60{ }^{\circ} \mathrm{C}, \mathrm{KWP}-1 / \mathrm{O}\right.$, Dakstar Plus, Poland) until light brown. Next, the bars were thermally treated until an internal temperature of $68^{\circ} \mathrm{C}$ was reached. Subsequently, bars were cooled down with water for $30 \mathrm{~min}$ up to $40^{\circ} \mathrm{C}$ and then cooled with air up to $\leq 10^{\circ} \mathrm{C}$. Final products were divided into 3 groups. The first group (" $\left.{ }^{\prime \prime}\right)$ was assigned for the immediate evaluation (right after the production). The second group ("7") was stored without packaging for 7 days at $4 \pm 2{ }^{\circ} \mathrm{C}$. The third group of meat products (" $\left.7 \mathrm{P}^{\prime}\right)$ was vacuum packed in multilayer PA/PE bags and stored for 7 days at $4 \pm 2{ }^{\circ} \mathrm{C}$.

Table 1. The recipe of meat products.

\begin{tabular}{cc}
\hline A. Raw Materials & \\
Pork & $8 \mathrm{~kg}$ \\
Pork jowl & $18 \mathrm{~kg}$ \\
Beef & $4 \mathrm{~kg}$ \\
\hline B. Additives & \\
\hline Sodium polyphosphate & $0.13 \mathrm{~kg}$ \\
Soy protein concentrate & $0.47 \mathrm{~kg}$ \\
Isoascorbate & $0.016 \mathrm{~kg}$ \\
Sweet pepper & $0.052 \mathrm{~kg}$ \\
Hot pepper & $0.052 \mathrm{~kg}$ \\
Concentrate of spices & $0.83 \mathrm{~kg}$ \\
Starch & $0.65 \mathrm{~kg}$ \\
Curing salt & $0.61 \mathrm{~kg}$ \\
Ice water & $10 \mathrm{~kg}$ \\
AFX/AE100/PANA4/FPRX & $0.18 / 0.29 / 0.86 / 0.14 \mathrm{~kg}$ \\
\hline
\end{tabular}


Table 1. Cont.

\begin{tabular}{cc}
\hline C. Support Materials: & \\
\hline Casings 26/28 & $1.04 \mathrm{~kg}$ \\
Flocks & $0.052 \mathrm{~kg}$ \\
\hline Total & $42.8 \mathrm{~kg}$ \\
Final product & $35.35 \mathrm{~kg}$ \\
\hline
\end{tabular}

\subsection{Information on the Use of the Functional Additives}

Four experimental variants containing commercial functional additives were prepared. The first 3 production variants (AFX, AE100, PANA4) contained a functional additive used for the first time in a production facility. Additives AFX, AE100 and PANA4 were introduced to replace the additive FPRX and were used in control samples.

AFX - product description: specialized liquid preparation consisting of water $98 \%$, flavor $1 \%$, spice extract $1 \%$, characterized by a light color, flavor and taste typical of its kind.

AE100 - product description: liquid preparation with natural antibacterial effect, consisting of water and spice extract. It has a liquid consistency, distinguished by a strong fresh taste and light brown color. The product was obtained through natural fermentation of spices which are characterized by high amounts of carbohydrates.

PANA4-product description: natural flavor obtained through fermentation of specifically selected food cultures and natural substrates. Improves palatability and extends shelf life. It has a liquid consistency, neutral $\mathrm{pH}$ and brown color. Contains sugars, salts of organic acids and aromas.

FRPX - product description: freshness-prolonging preparation with bacteriostatic effect. Composition: salt, glucose, maltodextrins, flavors, anti-caking agent E551. It is a white powder with a peculiar flavor.

The listed-above functional additives have been described and used in amounts consistent with the product specification.

\subsection{Microbiological Analysis}

In order to determine the microbiological safety of the final products, the total number of aerobic mesophilic bacteria and the number of Listeria monocytogenes were measured. The evaluation of the total amount of microorganisms was performed through the horizontal method for enumeration of microorganisms that are able to grow and form colonies in a solid medium after the aerobic incubation at $30{ }^{\circ} \mathrm{C}$ [12]. Detection and enumeration of Listeria monocytogenes were performed according to the horizontal method described in the standard PN-EN ISO 11290-2:2017-07 [13].

\subsection{Organoleptic Evaluation}

The organoleptic evaluation consisted of consumer assessment and quantitative flavor profiling (QFP). The consumer assessment was performed by 3 trained panelists with the basic knowledge of food analysis. In addition, they were well acquainted with the technological process. The samples were evaluated on the day of the production. Each time, the sausages were heated in an aqueous medium up to $60^{\circ} \mathrm{C}$. The thermometer was kept at that level for $5 \mathrm{~min}$. Then, the product was placed on a plate and served for evaluation. Panelists were asked to determinate the degree of acceptance by giving an appropriate score on a 5 -point hedonic rating scale $(1=$ dislike very much, $2=$ dislike slightly, $3=$ neither like nor dislike, $4=$ like slightly, $5=$ like very much [14]). The first feature evaluated by the panelists was the external appearance of the product. The following were taken into account: the degree of uniformity of color, the presence of intestinal villi, light spots, caused by under-smoking at the point of contact between the bar and the smoking stick or discoloration originating from the contact of the sausages with one another while smoking. The sausages were then cut along the vertical axis and their appearance in cross-section was evaluated. In that case, the homogeneity and color were assessed. Finally, taste and 
smell were evaluated. The analyses conducted in the meat processing plant were carried out at room temperature and under white light.

The second stage of the study was the quantitative flavor profiling (QFP). A group of panelists was given appropriate descriptions for scoring on a scale of 1-9 (from $1=$ absent to $9=$ far too intense), derived from the specifications of one of the preservatives used (PANA4). The panelists sought to identify individual attributes unanimously and created a common product description. The panelists evaluated the following attributes: taste, aftertaste (taste stability), appearance and texture. Among the elements belonging to the taste category, there were such discretions as: bitter taste, resulting from the smoking process, cooked pork taste, connected with the quality and freshness of the meat raw material used for production, and salty and peppery taste. The group of the aftertaste characteristics included the evaluation of saltiness and the degree of intensity of the aftertaste. When scoring appearance, only color was focused on. The group of texture traits included firmness when biting and slicing [14,15].

\subsection{Statistical Analysis}

For statistical analysis, TIBCO Statistica, version 13.3 (TIBCO Software Inc., Palo Alto, CA, USA) was used. Variables were analyzed by one-way analysis of variance (ANOVA) and Duncan's multiple range test was conducted after the homogeneity of variance had been confirmed. All tests were carried out at the significance level $p<0.05$.

\section{Results and Discussion}

Meat products, due to their high water activity and chemical composition, constitute a perfect ground for the growth of various microflora, which in turn leads to spoilage and reduced health safety [16]. Statistical analysis of the results (Table 2) showed a significant effect $(p<0.05)$ of storage time on the total number of aerobic mesophilic bacteria. After storage studies, it was found that the effectiveness of selected functional additives was unsatisfactory in most cases, as sausages produced with their use lose their shelf life after 7 days of storage under refrigeration conditions of $4-6^{\circ} \mathrm{C}$.

Table 2. Microbiological analysis of meat products (cfu in $1 \mathrm{~g}$ ).

\begin{tabular}{cccc}
\hline Samples & $\begin{array}{c}\text { Total Number of Aerobic } \\
\text { Mesophilic Bacteria }\end{array}$ & $\begin{array}{c}\text { Expanded } \\
\text { Uncertainty U }\end{array}$ & $\begin{array}{c}\text { Number of Listeria } \\
\text { monocytogenes }\end{array}$ \\
\hline AFX (0) & $4.06 \times 10^{3} \mathrm{Aa}$ & $\left(2.97 \times 10^{3} ; 5.63 \times 10^{3}\right)$ & $<1.0 \times 10^{1}$ \\
AFX (7) & $2.8 \times 10^{7} \mathrm{ABb}$ & $\left(2.06 \times 10^{7} ; 3.73 \times 10^{7}\right)$ & $<1.0 \times 10^{1}$ \\
AFX (7P) & $6.86 \times 10^{7} \mathrm{Cc}$ & $\left(5.16 \times 10^{7} ; 9.13 \times 10^{7}\right)$ & $<1.0 \times 10^{1}$ \\
\hline AE100 (0) & $1.1 \times 10^{4} \mathrm{Aa}$ & $\left(0.83 \times 10^{4} ; 1.46 \times 10^{3}\right)$ & $<1.0 \times 10^{1}$ \\
AE100 (7) & $2.5 \times 10^{9} \mathrm{Ec}$ & $\left(1.85 \times 10^{9} ; 3.43 \times 10^{9}\right)$ & $<1.0 \times 10^{1}$ \\
AE100 (7P) & $4.76 \times 10^{7} \mathrm{BCb}$ & $\left(3.63 \times 10^{7} ; 6.80 \times 10^{7}\right)$ & $<1.0 \times 10^{1}$ \\
PANA4 (0) & $1.76 \times 10^{5} \mathrm{Aa}$ & $\left(1.34 \times 10^{5} ; 2.33 \times 10^{5}\right)$ & $<1.0 \times 10^{1}$ \\
PANA4 (7) & $1.56 \times 10^{7} \mathrm{Ac}$ & $\left(1.25 \times 10^{7} ; 2.10 \times 10^{7}\right)$ & $<1.0 \times 10^{1}$ \\
PANA4 (7P) & $1.26 \times 10^{6} \mathrm{Ab}$ & $\left(0.93 \times 10^{6} ; 1.63 \times 10^{6}\right)$ & $<1.0 \times 10^{1}$ \\
\hline FPRX (0) & $2.27 \times 10^{3} \mathrm{Aa}$ & $\left(1.70 \times 10^{3} ; 3.10 \times 10^{3}\right)$ & $<1.0 \times 10^{1}$ \\
FPRX (7) & $9.33 \times 10^{7} \mathrm{Dc}$ & $\left(7.23 \times 10^{7} ; 1.23 \times 10^{7}\right)$ & $<1.0 \times 10^{1}$ \\
FPRX (7P) & $7.33 \times 10^{6} \mathrm{Ab}$ & $\left(5.46 \times 10^{6} ; 9.80 \times 10^{6}\right)$ & \\
\hline A-E & & & \\
\hline
\end{tabular}

A-E-means with different capital letters within the same column are significantly different at $p<0.05$; a-c-means with different small letters within the same samples are significantly different at $p<0.05$.

The highest increase in the total bacterial count was recorded in sausages made with FPRX functional additive. Most samples stored in bulk had higher bacterial counts than those in the vacuum pack. Samples produced with the addition of AFX, AE100 and FPRX showed characteristics indicating spoilage after 7 days of storage, i.e., slime or white film on the surface of the product or unpleasant odor. The first two additives contained spice 
extract in their composition; thus, one could expect their better inhibition of bacterial growth. Numerous articles have described in vitro activity of spices against Gram-positive and Gram-negative bacteria, yeasts and molds [17]. Where this antimicrobial activity may vary according to the origin and bioactive compounds of spice, different bacteria can also react in different ways [18]. Several studies have proven possible applications for spices and their derivatives as antimicrobial agents in meat products. For instance, Zhang et al. [19] reported the antimicrobial effect of a combination of rosemary extract $0.5 \%(v / w)$ and clove extract $0.5 \%(v / w)$ in raw chicken samples stored at $4 \pm 1{ }^{\circ} \mathrm{C}$ for 15 days. The same effect of clove, oregano, cinnamon, and black mustard extracts confirmed by Radha et al. [20]. Hernández-Ochoa et al. [21] proved that cumin and clove essential oils inhibited the growth of total bacteria by $3.78 \log \mathrm{CFU} / \mathrm{g}$ when applied on lean meat pulp. In another experiment, bay leaf essential oil was able to reduce the population of total coliforms (reduction of $2.8 \log$ CFU/g) and extended the shelf life of fresh Tuscan sausages for 2 days [22]. The cited studies indicate the antibacterial properties of spices in model systems, but only few additives of natural origin are currently applied on the market, e.g., essential oil of rosemary, of which its use as an antimicrobial and antioxidant agent in heat-treated processed meats is limited by the Commission Regulation (EU) No 1129/2011 [5] (only dry sausages mx. $100 \mathrm{mg} / \mathrm{kg}$, excluding dried sausages and dehydrated meat max. $150 \mathrm{mg} / \mathrm{kg}$ ). In our own studies, the antimicrobiological effect of spice extracts contained, as declared, in commercial AFX, AE100 additives was not demonstrated. Only the commercial functional additive PANA4 proved to be more effective against the growth of aerobic mesophilic bacteria during storage. With its application, the meat product did not show undesirable changes that would disqualify it for consumption. The effectiveness of this additive was also evaluated after 14 days of storage, and the effect was similar; the products also showed no signs of spoilage. The higher effectiveness of the PANA4 additive may be related to the presence of organic acid salts in its formulation. Short chain organic acids and/or their salts have GRAS status, and due to their inhibitory effect on bacteria and molds, are often used as chemical antimicrobial agents against pathogenic microflora [23-25]. Studies by many authors have confirmed the inhibitory activity of, for example, acetate, lactate and citrate sodium salts against spoilage bacteria and foodborne pathogens, i.e., Staphylococcus aureus, Yersinia enterocolitica, Escherichia coli, Clostridium botulinum and Listeria monocytogenes [26-29]. Consumption of food contaminated with the latter bacteria causes listeriosis, a disease that is rare but is often severe with high hospitalization and mortality rates. Listeria is not thermoresistant; thus, the treatment above $65{ }^{\circ} \mathrm{C}$ degrees is effective against it. Therefore, the biggest problem in food production is that it can occur after heat treatment, and Listeria monocytogenes tolerates salty environments and can even multiply during cold storage [30]. The results of Listeria monocytogenes detection in meat products are included in Table 2. Each of the selected functional additives was highly effective in inhibiting the growth of Listeria monocytogenes. In each sample, the bacterial count was $<1.0 \times 10^{1} \mathrm{CFU}$ in $1 \mathrm{~g}$, which is in accordance with the requirements of Commission Regulation (EC) No 2073/2005 of 15 November 2005 on microbiological criteria for foodstuffs [31]. The outcomes of our own research may also result in properly conducted thermal processing and hot smoking, effective temperature control throughout food production, and maintaining good hygienic practice in the meat processing plant.

The results of the organoleptic evaluation are presented in Table 3. The samples of the meat products manufactured with PANA4 were assessed at their best in terms of all the analyzed characteristics. The addition of AE100 to the recipe resulted in a much lower acceptability of the external and cross-section appearance, taste and smell of the meat products. The same negative effect on flavor, i.e., undesirable and untypical flavor, was observed by Tomović et al. [32] when incorporating Juniperus communis L. essential oil into dry fermented sausages. In our own studies, despite lower ratings of the listed sensory characteristics and overall acceptability of the samples with AFX and FPRX, they were scored as good (4 points in a 5 points scale). In contrast, adding green tea powder in production of lamb sausages negatively affected the sensory quality since the score of 
acceptability reduced in the group of sausages contained green tea while the scores for color, flavor, and odor were higher than in samples without its addition [33]. Conscious consumers expect food with the most natural composition but that is safe for their health and life, hence the need of producers and researchers to look for solutions that will meet these expectations without causing nutritional and organoleptic losses [34]. The proposed solutions should be aimed at maintaining the stability of meat characteristics to prevent undesirable modifications during storage time [35]. The results of our own study indicate that the application of PANA4 in the recipe of meat products resulted in the desired organoleptic characteristics, while ensuring their microbiological quality.

Table 3. Consumer analysis of organoleptic characteristics of meat products.

\begin{tabular}{|c|c|c|c|c|c|c|c|c|c|}
\hline \multirow{2}{*}{ Characteristic } & \multicolumn{4}{|c|}{$\begin{array}{l}\text { Assessment of Individual } \\
\text { Characteristics }\end{array}$} & \multirow{2}{*}{ Weighting Factor } & \multicolumn{4}{|c|}{$\begin{array}{l}\text { Score of Individual } \\
\text { Characteristics } \times \text { Weighting Factor }\end{array}$} \\
\hline & AFX & AE100 & PANA4 & FPRX & & AFX & AE100 & PANA4 & FPRX \\
\hline $\begin{array}{l}\text { external } \\
\text { appearance }\end{array}$ & 3.7 & 3.7 & 4.5 & 4.0 & 0.2 & 0.7 & 0.7 & 1.0 & 0.8 \\
\hline $\begin{array}{l}\text { cross-section } \\
\text { appearance }\end{array}$ & 3.3 & 3.7 & 4.7 & 4.0 & 0.4 & 1.3 & 1.4 & 1.9 & 1.6 \\
\hline taste and smell & 5 & 2.3 & 4.7 & 4.0 & 0.4 & 2.0 & 0.9 & 1.9 & 1.6 \\
\hline overall assessment $\left(\sum\right)$ & - & - & - & - & - & 4.0 & 3.1 & 4.8 & 4.0 \\
\hline
\end{tabular}

Quantitative flavor profiling (Figure 1) revealed that the intensity of light brown color and flavor bouquet were rated as medium in samples AFX and PANA4. These samples were also characterized by the same level of intensity of meat aroma. According to the product specifications, additive AFX contains flavor, and additive PANA4 is added to enhance palatability, which was achieved in experimental trials. The firmness on slicing and biting was optimal in variants with AFX addition. Meat products manufactured with addition of this additive are characterized by higher intensity of pepper flavor. The taste of cooked pork was the least intense in the samples FPRX and, on average, was too intense in the samples AE100. The intensity of this taste is reflected in the organoleptic evaluation, in which the taste and smell of the samples produced with additive AE100 were rated as the lowest of all the variants.

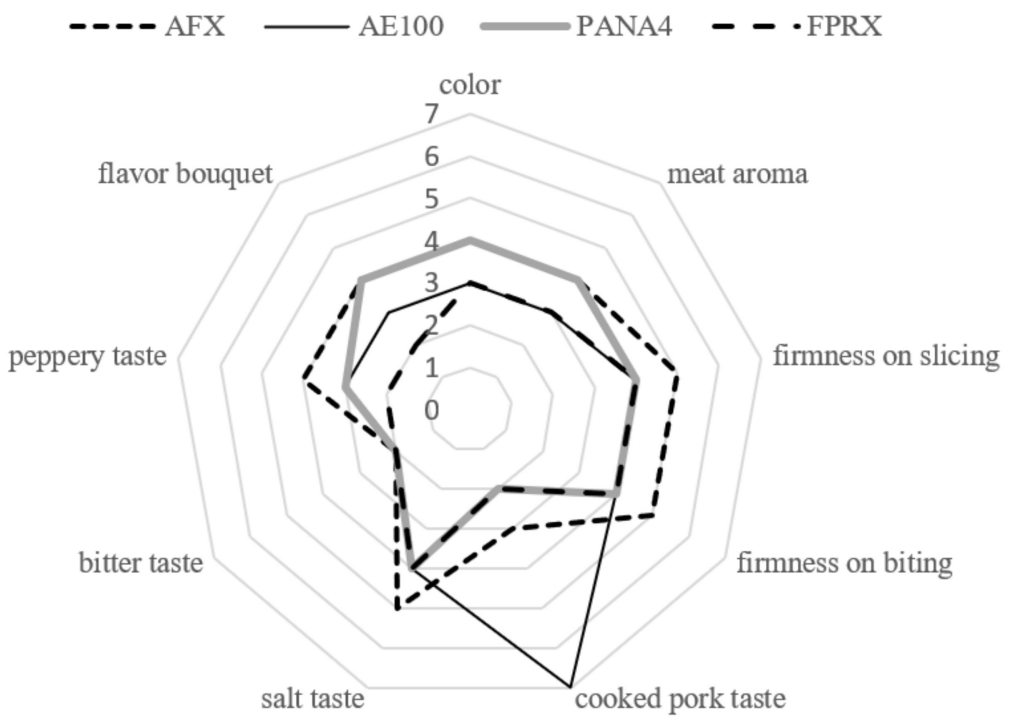

Figure 1. Quantitative flavor profiling of meat products.

\section{Conclusions}

In conclusion, the functional additives used differed in shaping the organoleptic as well as microbiological quality of meat products. Additives AFX and PANA4 had a 
beneficial effect on the appearance, taste and smell of the evaluated products. However, only the latter effectively reduced microbiological spoilage of the products during storage. Therefore, it can be successfully applied in the meat industry as a functional agent affecting organoleptic quality as well as safety of meat products. All additives were effective in limiting the growth of Listeria monocytogenes; therefore, the authors suggest further studies on the effectiveness of these functional additives in an altered system, i.e., after the introduction of other additives of natural origin to the recipe, which would synergistically affect the organoleptic characteristics of the products.

Author Contributions: Conceptualization, I.C. and G.K.; methodology, G.K. and I.C.; validation, I.C.; formal analysis, A.F. and A.M.S.; investigation, A.F. and I.C.; resources, I.C.; data curation, A.F. and A.M.S.; writing—original draft preparation, A.F., G.K. and A.M.S.; writing—review and editing, A.M.S.; visualization, A.M.S.; supervision, I.C. and G.K.; project administration, G.K.; funding acquisition, I.C., G.K. and A.M.S. All authors have read and agreed to the published version of the manuscript.

Funding: The manuscript was co-funded by the support project from the subsidy increased for the period 2020-2025 in the amount of 2\% of the subsidy referred to Art. 387 (3) of the Law of 20 July 2018 on Higher Education and Science, obtained in 2019.

Institutional Review Board Statement: Not applicable.

Informed Consent Statement: Not applicable.

Data Availability Statement: All available data is provided in the results section of this paper.

Conflicts of Interest: The authors declare no conflict of interest.

\section{References}

1. Cenci-Goga, B.T.; Iulietto, M.F.; Sechi, P.; Borgogni, E.; Karama, M.; Grispoldi, L. New Trends in Meat Packaging. Microbiol. Res. 2020, 11, 56-67. [CrossRef]

2. Pundir, R.K.; Jain, P. Evaluation of five chemical food preservatives for their antibacterial activity against bacterial isolates from bakery products and mango pickles. J. Chem. Pharm. Res. 2011, 3, 24-31.

3. OJ L 354. Regulation (EC) No 1333/2008 of the European Parliment and of the Council of 16 December 2008 on Food Additives. Available online: https:/ / eur-lex.europa.eu/legal-content/EN/LSU/?uri=CELEX:32008R1333 (accessed on 22 November 2021).

4. Sośnicka, M. Natural preservatives in meat products. Biotechnol. Food Sci. 2019, 83, 107-120.

5. OJ 295. Commission Regulation (EU) No 1129/2011 of 11 November 2011 Amending Annex II to Regulation (EC) No 1333/2008 of the European Parliament and of the Council by Establishing a Union List of Food Additives. Available online: https: / / eur-lex.europa.eu/legal-content/EN/ALL/?uri=CELEX\%3A32011R1129 (accessed on 22 November 2021).

6. Horbańczuk, O.K.; Kurek, M.A.; Atanasov, A.G.; Brnčić, M.; Rimac Brnčić, S. The effect of natural antioxidants on quality and shelf life of beef and beef products. Food Technol. Biotechnol. 2019, 57, 439-447. [CrossRef] [PubMed]

7. Perales-Jasso, Y.J.; Gamez-Noyola, S.A.; Aranda-Ruiz, J.; Hernandez-Martinez, C.A.; Gutierrez-Soto, G.; Luna-Maldonado, A.I.; Silva-Vazquez, R.; Hume, M.E.; Mendez-Zamora, G. Oregano powder substitution and shelf life in pork chorizo using Mexican oregano essential oil. Food Sci. Nutr. 2018, 6, 1254-1260. [CrossRef] [PubMed]

8. Shan, B.; Cai, Y.-Z.; Brooks, J.D.; Corke, H. Antibacterial and antioxidant effects of five spice and herb extracts as natural preservatives of raw pork. J. Sci. Food Agric. 2009, 89, 1879-1885. [CrossRef]

9. Ahmed, A.M.; Ismail, T.H. Improvement of the quality and shelf-life of minced-beef mixed with soyprotein by Sage (Salvia officinalis). Afr. J. Food Sci. 2010, 4, 330-334.

10. Busatta, C.; Vidal, R.S.; Popiolski, A.S.; Mossi, A.J.; Dariva, C.; Rodrigues, M.R.A.; Corazza, F.C.; Corazza, M.L.; Oliveira, V.J.; Cansian, R.L. Application of Origanum majorana L. essential oil as an antimicrobial agent in sausage. Food Microbiol. 2008, 25, 207-211. [CrossRef]

11. Krisch, J.; Pardi, Z.; Tserennadmid, R.; Papp, T.; Vágvölgyi, C. Antimicrobial effects of commercial herbs, spices and essential oils in minced pork. Acta Biol. Szeged. 2010, 54, 131-134.

12. PN-EN ISO 4833-1:2013-12 Microbiology of the Food Chain-Horizontal Method for the Enumeration of Microorganisms-Part 1: Colony Count at $30{ }^{\circ} \mathrm{C}$ by the Pour Plate Technique. Available online: https://www.iso.org/standard/53728.html (accessed on 30 November 2021).

13. PN-EN ISO 11290-2:2017-07 Microbiology of Food and Animal Feeding Stuffs-Horizontal Method for the Detection and Enumeration of Listeria monocytogenes-Part 1: Detection Method. Available online: https://www.iso.org/standard/60313.html (accessed on 30 November 2021).

14. Lewless, H.T.; Hildegarde, H. Sensory Evaluation of Food. Principles and Practices, 2nd ed.; Springer: Berlin, Germany, 2010. 
15. Arildsen Jakobsen, L.M.; Vuholm, S.; Aaslyng, M.D.; Kristensen, M.; Sørensen, K.V.; Raben, A.; Kehlet, U. Sensory characteristics and consumer liking of sausages with 10\% fat and added rye or wheat bran. Food Sci. Nutr. 2014, 2, 534-546. [CrossRef]

16. Dave, D.; Ghaly, A.E. Meat spoilage mechanisms and preservation techniques: A critical review. Am. J. Agric. Biol. Sci. 2011, 6, 486-510.

17. Tajkarimi, M.M.; Ibrahim, S.A.; Cliver, D.O. Antimicrobial herb and spice compounds in food. Food Control 2010, 21, 1199-1218. [CrossRef]

18. Hyldgaard, M.; Mygind, T.; Meyer, R.L. Essential oils in food preservation: Mode of action, synergies, and interactions with food matrix components. Front. Microbiol. 2012, 3, 12. [CrossRef]

19. Zhang, H.; Wu, J.; Guo, X. Effects of antimicrobial and antioxidant activities of spice extracts on raw chicken meat quality. Food Sci. Hum. Wellness 2016, 5, 39-48. [CrossRef]

20. Radha, K.K.; Babuskin, S.; Azhagu Saravana Babu, P.; Sasikala, M.; Sabina, K.; Archana, G.; Sivarajan, M.; Sukumar, M. Antimicrobial and antioxidant effects of spice extracts on the shelf life extension of raw chicken meat. Int. J. Food Microbiol. 2014, 171, 32-40. [CrossRef]

21. Hernández-Ochoa, L.; Aguirre-Prieto, Y.B.; Nevárez-Moorillón, G.V.; Gutierrez-Mendez, N.; Salas-Salas-Muñoz, E. Use of essential oils and extracts from spices in meat protection. J. Food Sci. Technol. 2014, 51, 957-963. [CrossRef]

22. Da Silveira, S.M.; Luciano, F.B.; Fronza, N.; Cunha, A.; Scheuermann, G.N.; Vieira, C.R.W. Chemical composition and antibacterial activity of Laurus nobilis essential oil towards foodborne pathogens and its application in fresh Tuscan sausage stored at $7{ }^{\circ} \mathrm{C}$. LWT-Food Sci. Technol. 2014, 59, 86-93. [CrossRef]

23. Wang, H.; Provan, G.J.; Helliwell, K. Tea flavonoids: Their functions, utilization and analysis. Trends Food Sci. Technol. 2000, 11, 152-160. [CrossRef]

24. Zainab, D.; Abd-Aladheem, H.; Naeem, F. Influence of some weak acids, weak bases and salts against some pathogenic microorganisms. Univ. Thi-Qar J. Med. 2011, 5, 93-99.

25. Sánchez-Maldonado, A.; Schieber, A.; Ganzle, M.G. Structure function relationships of the antibacterial activity of phenolic acids and their metabolism by lactic acid bacteria. J. Appl. Microbiol. 2011, 111, 1176-1184. [CrossRef] [PubMed]

26. Bidlas, E.; Lambert, R.J. Comparing the antimicrobial effectiveness of $\mathrm{NaCl}$ and $\mathrm{KCl}$ with a view to salt/sodium replacement. Int. J. Food Microbiol. 2008, 124, 98-102. [CrossRef] [PubMed]

27. Lee, Y.L.; Cesario, T.; Owens, J.; Shanbrom, E.; Thrupp, L.D. Antibacterial activity of citrate and acetate. Nutrition 2002, 18, 665-666. [CrossRef]

28. McWilliam, E.C.; Stewart, C.S. Susceptibility of Escherichia coli O157 isolates to lactate. Lett. Appl. Microbiol. 2002, 35, 176-180. [CrossRef]

29. Qvist, S.; Sehested, K.; Zutyhen, P. Growth suppression of Listeria monocytogenes in a meat product. Int. J. Food Microbiol. 1994, 24, 283-293. [CrossRef]

30. Available online: https://www.efsa.europa.eu/en/topics/topic/listeria (accessed on 22 November 2021).

31. OJ L 338. Commission Regulation (EC) No 2073/2005 of 15 November 2005 on Microbiological Criteria for Foodstuffs. Available online: https: / / eur-lex.europa.eu/legal-content/EN/TXT/PDF/?uri=CELEX:02005R2073-20140601\&from=DA (accessed on 22 November 2021).

32. Tomović, V.; Šojić, B.; Savanović, J.; Kocić-Tanackov, S.; Pavlić, B.; Jokanović, M.; Đorđević, V.; Parunović, N.; Martinović, A.; Vujadinović, D. New Formulation towards Healthier Meat Products: Juniperus communis L. Essential Oil as Alternative for Sodium Nitrite in Dry Fermented Sausages. Foods 2020, 9, 1066. [CrossRef]

33. Purnamayanti, L.; Jamhari, J.; Hanim, C.; Irawan, A. Physicochemical properties, oxidative stability, and sensory quality of lamb sausage added with green tea leaves (Camelia Sinensis) powder. Trop. Anim. Sci. J. 2020, 43, 57-63. [CrossRef]

34. Del Nobile, M.A.; Lucera, A.; Costa, C.; Conte, A. Food applications of natural antimicrobial compounds. Front. Microbiol. 2012, 3, 287. [CrossRef]

35. Iulietto, M.F.; Sechi, P.; Borgogni, E.; Cenci-Goga, B.T. Meat spoilage: A critical review of a neglected alteration due to ropy slime producing bacteria. Ital. J. Anim. Sci. 2015, 14, 4011. [CrossRef] 